\title{
Strategies to improve the implementation of nurse- initiated management of antiretroviral therapy (NIMART) training: a systematic review
}

Sheillah Hlamalani Mboweni

Aurum Institute for Health Research

LUFUNO MAKHADO ( $\square$ lufuno.makhado@univen.ac.za)

University of Venda https://orcid.org/0000-0003-1689-9308

Research article

Keywords: NIMART training, impact, HIV management, task shifting, training strategies

Posted Date: March 5th, 2020

DOI: https://doi.org/10.21203/rs.3.rs-16220/v1

License: (c) (i) This work is licensed under a Creative Commons Attribution 4.0 International License. Read

Full License 


\section{Abstract}

Background Nurse-Initiated Management of Antiretroviral Therapy (NIMART) training was introduced with the purpose of improving the knowledge, skills and competence of nurses in providing comprehensive quality care to people living with HIV (PLWH) and facilitating World Health Organisation task-shifting where nurses initiate antiretroviral therapy (ART) rather than doctors to meet the increasing demand of ART drugs. The aim of this review was to identify evidence of training strategies that can improve the implementation and deals with challenges that hinder quality. Methods A measurement tool to assess systematic reviews methodological systematic review tool was used to critically assess selected studies. Studies were sought using multiple databases including CINAHL (EBSCO), Google Scholar, ProQuest, academic journals, SA publications, electronic resources and OAISTER published from January 2012 to February 2017. The initial review of studies yielded 535 results excluding duplications. The screening of full-text articles was conducted, and 33 articles met the eligibility criteria and were included for quality assessment. The rest were excluded. The quality assessment research instrument was used to analyse and synthesise selected full-text articles $(n=33)$. Results The studies indicate that NIMART or HIV training is used interchangeably and has the potential to empower nurses with knowledge and skills. It also has a positive impact on increasing ART uptake; however, nurses still lack confidence and competence to provide comprehensive quality patientcentred care. Studies suggest that a shift from the traditional didactics of lectures or slide presentation methods during training to the use of interactive training strategies that stimulate critical thinking in making decisions about HIV care, followed by mentoring and continuous professional development. Conclusion and recommendation This study reveals that the use of effective training techniques during NIMART training has a positive impact on the learning outcomes, implementation and performance of HIV programmes. The health care system should focus on dealing with barriers that negatively influence NIMART implementation. Given the lack of a framework or model related to NIMART or HIV training, the study recommends the development of a conceptual framework to strengthens the implementation of NIMART training.

\section{Background}

This researcher analysed the process of conducting a systematic literature review in studies done in South Africa and globally, from January 2012 to February 2017, on Nurse-Initiated Management of Antiretroviral Therapy (NIMART) or Human Immunodeficiency Virus (HIV) training. The two are used interchangeably in most literature. NIMART training was introduced in response to World Health Organisation (WHO) recommendations of task shifting to tackle the shortage of skilled health care workers, where nurses initiate ART rather than doctors with the aim of achieving the goal of universal access to comprehensive prevention programmes, treatment, quality care and support globally [1]. However, the implementation of NIMART after training and quality is of serious concern in the North West districts. There is a need to increase access to ART to meet the demand according to the South African guidelines and the current universal test and treat (UTT) policy introduced in September 2016 to achieve the 90-90-90 strategy and eventually better health for all people living with HIV (PLWH).

\section{Problem Statement}


The Regional Training Centres (RTC) were established to improve the skills of health care workers in order to respond effectively to HIV and AIDS care. The clinical mentorship programme had been introduced to strengthen the knowledge, skills, competencies and confidence of health care workers after training. In addition, guidelines were developed and reviewed according to research findings as well as in-service training was conducted to promote proper NIMART implementation. However, gaps still exist. This was observed during the quarterly and annual monitoring and review of HIV programmes using ART indicators which included HIV/tuberculosis (TB) co-infected, antenatal (ANC) pregnant women, new adults and children initiated on ART and a total number of patients remaining on ART, viral load completion and suppression rate. The general performance of these indicators is fluctuating, and no significant impact is observed despite the increasing number of nurses trained and certified competent. Therefore, this prompted the researcher to conduct a systematic investigation of literature to obtain a better understanding of the problem. Preferred Reporting Items for Systematic and meta-Analyses (PRISMA) was followed to ensure justification for further research and to address several conceptual and practical advances in science. The flow diagram summarised in Figure 1 of the systematic review phases was used [2].

\section{Aim of the study}

The purpose of this study was to review the literature to obtain a broader perspective of strategies that can be adopted for training and identifying challenges that hinder implementation and ways to deal with such factors. The objective of the study was to review and analyse primary studies that would provide an in-depth understanding of the facilitation strategies that can be used to strengthen NIMART training and to improve quality in the implementation and management of HIV programmes.

The following review questions were used:

- What is the impact of NIMART/HIV training on HIV management?

- What are the training strategies used in NIMART /HIV training?

- What are the factors affecting or influencing the implementation of HIV programmes?

Implementation is a process of moving an idea from concept to reality (dictionary)., Implementation is also defined as the process needed to bring new practices into widespread use [3]. Therefore, in this study, implementation refers to the process of acquiring knowledge and skills obtained from NIMART training to increase access to antiretroviral drugs (ARVs) and to provide quality comprehensive care through evidencebased practice.

NIMART training had been defined in accordance to the National Department of Health, it was nurses who initiated and managed antiretroviral therapy training in order to increase access to ART [4]. This is an organised process or activity of teaching nurses about nurse-initiated and management of ART by imparting knowledge about the HIV and AIDS, Sexual transmitted infections (STI) and Tuberculosis (TB) (HAST) programme, the provision of clinical mentorship to improve practical skills, confidence and competence in the delivery of comprehensive quality care, treatment and support within primary health care (PHC) level.

\section{Contribution of the study to NIMART training}


This study contributes to a broader understanding of training strategies that can be used by the RTC, facilitators and curriculum developers to improve the knowledge, skills, competency and confidence of nurses to provide comprehensive and quality care to PLWH, including being aware of challenges influencing implementation in the health care system. This will also provide a basis for improvement in training and implementation of NIMART, through the findings and recommendations made by researchers. The study also provides guidance to policymakers and district health care system management teams on ways to deal with challenges affecting the implementation and quality of HIV programmes.

\section{Methods}

\section{Search Strategy_}

The methodological quality of the systematic review process was critically assessed using the eleven components of the AMSTAR tool or checklist [5]. The following components were assessed by indicating yes, no, can't answer or not applicable: the design used, the removal of duplicates and data extraction, the performance of a comprehensive literature search, indication of studies that met inclusion and exclusion criteria and the reason, providing the list of included and excluded studies, providing a table with characteristics of included studies, the use of a quality scoring tool to assess studies and be documented, appropriate use of rigour and scientific quality in analysing and formulating conclusions, the use of appropriate tests, reduction of bias and disclosure of conflict of interest (refer to Annexure A).

\section{Information sources and search}

A manual search using selected terms was conducted with the help of an experienced librarian and researcher to ensure that the studies were critically analysed. The search terms were divided into three words and later combined. Different databases were searched, including CINAHL (EBCO), scholar Google, ProQuest, academic journals, SA publications, electronic resources and OAISTER. The nominated search terms are shown in Table 1 and databases in Table 2. Both qualitative, quantitative and mixed studies were reviewed for meta-analysis. The search strategy was documented, saved and stored online.

\section{Inclusion and exclusion criteria}

Literature with the following topics, published between Jan 2012 and Feb 2017 was included: NIMART OR HIV training, HIV management, factors influencing performance and the impact of NIMART OR HIV training.

The following types of papers were excluded: informal literature surveys with no defined research question or search, data extraction and data analysis process and papers not subjected to peer reviews. When a paper had been published in more than one journal, the most complete version of the study was used.

\section{Primary study selection}

After conducting the search, primary or original full-text studies were selected using the PICOS review protocol or criteria. These studies were assessed based on participants, phenomena of interest, context and type of studies as indicated in Table 3. The list of rejected studies was compiled indicating reasons for rejection, 
checked, discussed and agreed upon with an independent researcher. Most of the studies excluded were abstracts, magazines and newspaper articles.

\section{Quality_assessment}

The quality of the original studies chosen for the review was critically screened using the Quality Assessment Research Instrument (QUARI), developed by the Joanna Briggs Institute (JBI) in 2014, as indicated in Table 4. The QUARI has ten evaluation criteria, which include author, name, year, country, and purpose of the study, participants, design, data collection, data analysis and key findings [6]. Studies that had scored 5 or fewer points were excluded from the review to ensure quality.

\section{Data extracted and synthesis}

Full-text studies were extracted $(n=33)$ and considered for systematic review and analysis. Five were excluded, however, they were used in reference. Data from each paper was checked by another researcher. Microsoft Excel was used to capture, sort and arrange papers in alphabetical order according to the first authors and duplicates were removed (See Figure 1). The studies indicated on Table 4 was reviewed to answer the research questions and to identify interesting trends. Thematic analysis was used to synthesise data. Data were coded, categorised and themes were developed.

\section{Results}

The studies selected for analysis were conducted in South Africa, USA, Australia, Kenya, Uganda, Nigeria and Central African countries. Most of the studies were from the rural PHC of South Africa (45\%), followed by USA (30.3\%), Australia (3\%) and other African countries (15\%). The studies used different methods which included quantitative $(n=13)$, qualitative $(n=14)$ and mixed methods $(n=6)$. A total number of 33 studies were reviewed. Participants among the reviewed studies varied from 15 to 386 and they were mainly nurses, midwives, students, managers in health care, clinical documents, patients and nursing educators. Studies focused on the impact of NIMART or HIV training strategies ( $n=15)$, factors influencing NIMART or HIV implementation and management $(n=13)$ as well as those that focused on both training and implementation $(n=5)$. The following themes were developed:

\section{The Impact of NIMART/HIV training strategies on the implementation of HIV programmes}

Studies have confirmed that the strategy of nurses initiating ART rather than doctors has a positive impact on increasing ART uptake, although there are still challenges in NIMART training and implementation which affect the performance of HIV programmes as indicated in Table 5. NIMART training can have both positive and negative impacts depending on the strategies used during training $[7,8,9,10]$. Studies have revealed that nurses feel that NIMART training has empowered them with knowledge and skills to manage PLWH, however, there are still factors that influence implementation, competency and confidence to provide comprehensive quality care. This study's findings show that the use of ineffective, passive, traditional didactics methods of lecturing or slides presentation has no impact on learning and results in inadequate NIMART training. The use of multiple, interactive techniques that stimulate critical thinking to make sound decisions in care is recommended. These strategies include problem-based, reflective and case-based 
learning, seminar, clinical simulation, group discussions, practice and feedback. It increases knowledge and confidence in caring for PLWH.

Some studies have indicated that, in service, onsite or facility-based clinical training, continuous professional development, creating a pool of trainers and mentoring have a potential to improve the knowledge, competency and performance of indicators $[11,12,13,14,15,16]$. Pre-service training in the institutions of higher learning is necessary to prepare nurses to care for HIV patients immediately when they enter the health care system [17]. Additional training on Primary care 101 also has the potential of improving the quality of clinical records and the integration of the management of chronic diseases in the PHC clinics. This includes NCD and ART patients [18]. NIMART training includes paediatric HIV and TB /HIV co-infection management, adverse drug reaction, switching therapy and dealing with defaulters. However, nurses still call the hotline to request assistance in dealing with such cases or refer them to doctors. Very few nurses are competent to initiate ART to children and TB/HIV and some still need more practice and mentoring $[19,20,21]$. Another gap identified in NIMART is the lack of training in data management, data elements definition, ART, HTS, TB and other registers. This results in over- or under-reporting [22]. Consequently, inter-professional education, practice, ethics and professionalism are not emphasised in the clinical years of training and need sensitisation including enhancement of mentorship and the use of innovative training strategies [23].

\section{Factors influencing the implementation of NIMART/ HIV training}

Studies have revealed different factors, classified as patient, human resource (HR), environmental and structural/health system factors as indicated in Table 5. Nurses who have been trained on NIMART/HIV are reported to have gained knowledge and skills but face the burden of being overworked by high volumes of patients demanding ART. This results in exhaustion and dissatisfaction. High staff turnover leading to a shortage of skilled nurses and unverified data by OPM in the facilities affect the performance of indicators $[11,12,13,22,24]$.

The patients' factor also adds pressure to the implementation and management of ART. Studies have indicated that poor adherence to ART or TB treatment is associated with poor outcomes. Patients still have challenges regarding modification of lifestyle, e.g. the use of alcohol and it undermines adherence, leads to risky behaviour, alters the immune system and the physiological and effective functioning of drugs. Poor adherence was also evident with a high rate of loss to follow up especially patients who were on pre-ART care or wellness and need tracing and link to care $[25,26]$.

Some studies have revealed that the health care system or structural factors have negatively impacted NIMART implementation, especially in sub-Saharan Africa, including South Africa. This includes poor integration of services, lack of support, lack of supervision, long waiting hours, inadequate financial resources, equipment and drugs stock-outs, supply chain system, overcrowding, staff attitudes, monitoring and evaluation programmes and poor organisation of work schedules and processes (see Table 6) $[13,27$, $28,29,30]$. There are only three sub-Saharan countries are implementing ART according to WHO guidelines of treatment for all to achieve the 90-90-90 targets, including the universal test and treat policy [31].

Decentralisation of NIMART services increases ART uptake in PHC and rural clinics although it also increases workload $[14,31]$. NIMART is widely practised and authorised in policy but not reinforced in regulations, e.g. 
SANC, pre-service education [32]. a review of ART guidelines has resulted in early ART initiation and has public health benefits in reducing HIV incidences, morbidity and mortality [33]. However, facility-based inservice training before implementation and mentoring should be prioritised and provided compulsorily.

Environmental factors such as stigma, discrimination and staff attitudes impact negatively on NIMART /HIV implementation and management and contribute to poor adherence to treatment. Studies also support that poor infrastructure, a lack of space and overcrowding expose both clients and staff to cross-infection and affect HIV and TB management. Inadequate security poses a risk to staff, drugs and equipment. Poor clinical leadership role models, support and supervision by unit managers in developing student nurses also exist [34, 35].

\section{Discussion}

Studies have indicated that NIMART training has positively increased ART initiations by nurses, however, there are still challenges to improve training and in dealing with factors hindering quality implementation. Most studies have confirmed that the implementation of WHO recommendations of task-shifting on nurse-led ART programme in PHC have yielded a positive impact $[9,29]$. Hence, South Africa has the largest ART programme worldwide with about 3.4 million people [36]. Nurses have been reported to have gained knowledge and skills through NIMART training, but gaps still exist regarding competence, confidence and attitude necessary to sustain patients on lifelong ART and to ensure adherence to achieve viral load (VL) suppression. This has a negative impact in reducing new HIV and TB infections, drug resistance and death. Findings from this review suggest numerous barriers that have a negative impact on training and recommends various effective strategies to improve, as indicated in Table 5. The review has illustrated consistently that there are several factors that continue to impact NIMART implementation and hinder the performance of HIV and ART indicators. These include patient social, physical and psychological factors, environmental, structural or health care systems and human capital factors, as indicated in Table 6. Future studies need to consider identifying and finding ways to deal with barriers and should further develop a conceptual framework that will help to improve NIMART training and implementation as there was no framework in the literature reviewed.

\section{Practical implications}

Based on the findings and recommendations of the studies analysed, integration of theory and practice can be practically achieved by means of interactive critical thinking and training strategies. On the other hand, nurses would improve their decision-making skills and render quality HIV care to PLWH, thus improving the performance of the programme.

\section{Limitations of the studies}

The study only focused on full text, reviewed and published studies. Other studies were excluded as they did not comply with the approaches, even though it has valuable information. No conceptual framework or model related to NIMART/HIV training was identified. 


\section{Conclusions}

Although task-shifting and NIMART training have helped to increase ART uptake, more should be done to provide quality care to PLWH and to strengthen adherence, to reduce loss to follow up and to keep them virally suppressed. Again, measures to improve continuity of HIV care should include the use of interactive training strategies that stimulate critical thinking in decision making about HIV care. Dealing with factors that hinder implementation is of great importance and the development of a comprehensive integrated framework is necessary to guide NIMART training and implementation.

The study has revealed recommendations that can be used to improve the quality of training using strategies that stimulate critical thinking and integrate theory with practice. It is also recommended the introduction of NIMART as a pre-service training to nursing students, providing continuous in-service training on the current development and dealing with barriers affecting the implementation of HIV programmes in the PHC facilities to achieve better outcomes.

\section{Abbreviations}

AIDS- Acquired Immune Deficiency Syndrome

ANC- Antenatal Care; ART- Antiretroviral Therapy;

ARV- Antiretroviral;

CPD- Continuous Professional Development;

HAST- HIV and AIDS, STDs and Tuberculosis;

HIV- Human Immunodeficiency Virus;

HTS- HIV counselling and testing services;

LTFU Loss to Follow up;

NCD- Non-communicable disease;

NIMART- Nurse-Initiated Management of Antiretroviral Therapy;

NRF- National Research Foundation;

PHC- Primary Health Care;

PRISMA- Preferred reporting items for systematic and meta-analyses;

QA- Quality Assurance;

Q1- Quality Improvement; 
QUARI- Quality Assessment Research Instrument;

TB- Tuberculosis;

UTT- Universal Test and Treat;

VL- Viral Load;

WHO- World Health Organization

\section{Declarations}

\section{Ethics and consent to participate}

Not applicable

\section{Consent for publication}

Not applicable

\section{Availability of data material}

Not applicable

\section{Competing interest}

There is no financial or personal relationship that may have inappropriately influenced us in writing this article.

\section{Funding}

The study authors are grateful to the NRF (Thuthuka grant- TTK160601167061) for funding the study. The funder had no influence in whatsoever way with regard to the writing of this manuscript except funding the study.

\section{Author's contribution}

S.H.M and L.M conceptualised, designed the study, data collection through literature search independently, analysed and wrote the manuscript, edited and approved manuscript for the final submission.

\section{Acknowledgements}

A special thanks to the Librarian for the support, guidance and assistance in the literature search.

\section{References}


1. World Health Organization. Joint United Nations Program on HIV/AIDS. HIV/AIDS programme. Strengthening health services to fight HIV/AIDS. Guidance on provider-initiated HIV testing and counselling in health facilities. Geneva, Switzerland: WHO. 2007 Mar.

2. Moher D, Liberati A, Tetzlaff J, Altman DG. Preferred reporting items for systematic reviews and metaanalyses: the PRISMA statement. Annals of internal medicine. 2009 Aug 18;151(4):264-9.

3. Tout K, Metz A, Bartley L. Considering statewide professional development systems. Applying implementation science in early childhood programs and systems. 2013:243-68.

4. Department of Health. Clinical mentorship manual for integrated services.

5. Shea BJ, Grimshaw JM, Wells GA, Boers M, Andersson N, Hamel C, Porter AC, Tugwell P, Moher D, Bouter LM. Development of AMSTAR: a measurement tool to assess the methodological quality of systematic reviews. BMC medical research methodology. 2007 Dec;7(1):10..

6. Munn Z, Moola S, Riitano D, Lisy K. The development of a critical appraisal tool for use in systematic reviews addressing questions of prevalence. International journal of health policy and management. 2014 Aug;3(3):123.

7. Bluestone J, Johnson P, Fullerton J, Carr C, Alderman J, BonTempo J. Effective in-service training design and delivery: evidence from an integrative literature review. Human resources for health. 2013 Dec $1 ; 11(1): 51$.

8. Chew D, Jaworsky D, Thorne J, Ho M, Andany N, Morin C, Hoffman N, Henshaw C, Rourke SB, Fisher M, Rachlis A. Development, implementation, and evaluation of a student-initiated undergraduate medical education elective in HIV care. Medical teacher. 2012 May 1;34(5):398-403.

9. Iwu EN, Holzemer WL. Task shifting of HIV management from doctors to nurses in Africa: clinical outcomes and evidence on nurse self-efficacy and job satisfaction. AIDS care. 2014 Jan 2;26(1):42-52.

10. Ousman K, Polomano RC, Seloilwe E, Odero T, Tarimo E, Mashalla YJ, Voss JG, O'Malley G, Chapman SA, Gachuno O, Manabe Y. Interprofessional fellowship training for emerging global health leaders in Africa to improve HIV prevention and care: the Afya Bora Consortium. Journal of the Association of Nurses in AIDS Care. 2016 May 1;27(3):331-43.

11. Davies NE, Homfray M, Venables EC. Nurse and manager perceptions of nurse initiated and managed antiretroviral therapy (NIMART) implementation in South Africa: a qualitative study. BMJ open. 2013 Nov 1;3(11):e003840.

12. Mack N, Wong C, McKenna K, Lemons A, Odhiambo J, Agot K. Human resource challenges to integrating HIV pre-exposure prophylaxis (PrEP) into the public health system in Kenya: a qualitative study. African journal of reproductive health. 2015;19(1):54-62.

13. Mbonye MK, Burnett SM, Naikoba S, Ronald A, Colebunders R, Van Geertruyden JP, Weaver MR. Effectiveness of educational outreach in infectious diseases management: a cluster randomized trial in Uganda. BMC public health. 2016 Dec;16(1):714.

14. Nyasulu JC, Muchiri E, Mazwi S, Ratshefola M. NIMART rollout to primary healthcare facilities increases access to antiretrovirals in Johannesburg: An interrupted time series analysis. South African Medical Journal. 2013;103(4):232-6. 
15. Oladele EA, Khamofu H, Asala S, Saleh M, Ralph-Opara U, Nwosisi C, Anyaike C, Gana C, Adedokun O, Dirks R, Adebayo O. Playing the catch-up game: accelerating the scale-up of prevention of mother-to-child transmission of HIV (PMTCT) services to eliminate new pediatric HIV infection in Nigeria. PloS one. 2017;12(1).

16. Owens A, Moroney T. Shifting the load: Improving bioscience performance in undergraduate nurses through student focused learning. Collegian. 2017 Feb 1;24(1):37-43.

17. Kurth AE, Jacob S, Squires AP, Sliney A, Davis S, Stalls S, Portillo CJ. Investing in nurses is a prerequisite for ensuring universal health coverage. Journal of the Association of Nurses in AIDS Care. 2016 May $1 ; 27(3): 344-54$.

18. Mahomed $\mathrm{OH}$, Naidoo S, Asmall S, Taylor M. Improving the quality of nurse clinical documentation for chronic patients at primary care clinics: A multifaceted intervention. Curationis. 2015;38(1):1-2.

19. Smith J, Odera DN, Chege D, Muigai EN, Patnaik P, Michaels-Strasser S, Howard AA, Yu-Shears J, Dohrn J. Identifying the gaps: An assessment of nurses' training, competency, and practice in HIV care and treatment in Kenya. Journal of the Association of Nurses in AIDS Care. 2016 May 1;27(3):322-30.

20. Swart AM, Chisholm BS, Cohen K, Workman LJ, Cameron D, Blockman M. Analysis of queries from nurses to the South African National HIV \& TB Health Care Worker Hotline. Southern African Journal of HIV Medicine. 2013;14(4):179-82.

21. Kufa T, Hippner P, Charalambous S, Kielmann K, Vassall A, Churchyard GJ, Grant AD, Fielding KL. A cluster randomised trial to evaluate the effect of optimising TB/HIV integration on patient level outcomes: The "merge" trial protocol. Contemporary clinical trials. 2014 Nov 1;39(2):280-7.

22. Kaposhi BM, Mqoqi N, Schopflocher D. Evaluation of antiretroviral treatment programme monitoring in Eastern Cape, South Africa. Health policy and planning. 2015 Jun 1;30(5):547-54.

23. Byakika-Kibwika, P., Kutesa, A., Baingana, R., Muhumuza, C., Kitutu, F.E., Mwesigwa, C., Chalo, R.N. and Sewankambo, N.K., 2015. A situation analysis of inter-professional education and practice for ethics and professionalism training at Makerere University College of Health Sciences. BMC research notes, 8(1), p.598.

24. Spies LA, Gray J, Opollo J, Mbalinda S. HIV and nurses: a focus group on task shifting in Uganda. Journal of the Association of Nurses in AIDS Care. 2016 May 1;27(3):312-21.

25. Knight M, Van Zyl RL, Sanne I, Bassett J, Van Rie A. Impact of combination antiretroviral therapy initiation on adherence to antituberculosis treatment. Southern African journal of HIV medicine. 2015;16(1):1-6.

26. Kompala T, Moll AP, Mtungwa N, Brooks RP, Friedland GH, Shenoi SV. Impact of nurse-delivered community-based CD4 services on facilitating pre-ART care in rural South Africa. BMC health services research. 2016 Dec;16(1):374.

27. Mathibe MD, Hendricks SJ, Bergh AM. Clinician perceptions and patient experiences of antiretroviral treatment integration in primary health care clinics, Tshwane, South Africa. curationis. 2015;38(1):1-1.

28. Uwimana J, Jackson D, Hausler H, Zarowsky C. Health system barriers to implementation of collaborative TB and HIV activities including prevention of mother to child transmission in South Africa. Tropical Medicine \& International Health. 2012 May;17(5):658-65. 
29. Uebel K, Guise A, Georgeu D, Colvin C, Lewin S. Integrating HIV care into nurse-led primary health care services in South Africa: a synthesis of three linked qualitative studies. BMC Health Services Research. 2013 Dec;13(1):171.

30. Gupta S, Granich R. When will sub-Saharan Africa adopt HIV treatment for all?. Southern African journal of HIV medicine. 2016;17(1):1-6.

31. Omole OB, Semenya MA. Treatment outcomes in a rural HIV clinic in South Africa: Implications for health care. Southern African journal of HIV medicine. 2016;17(1).

32. Zuber A, McCarthy CF, Verani AR, Msidi E, Johnson C. A survey of nurse-initiated and-managed antiretroviral therapy (NIMART) in practice, education, policy, and regulation in east, central, and southern Africa. Journal of the Association of Nurses in AIDS Care. 2014 Nov 1;25(6):520-31.

33. Meintjes G, Black J, Conradie F, Dlamini S, Maartens G, Manzini TC, Mathe M, Moorhouse M, Moosa Y, Nash J, Orrell C. Southern African HIV Clinicians Society adult antiretroviral therapy guidelines: Update on when to initiate antiretroviral therapy. Southern African journal of HIV medicine. 2015;16(1):1-4.

34. Ndubuka NO, Lim HJ, van der Wal DM, Ehlers VJ. Erratum: Health-related quality of life of antiretroviral treatment defaulters in Botswana. Southern African journal of HIV medicine. 2016;17(1).

35. Walker R, Cooke M, Henderson A, Creedy DK. Characteristics of leadership that influence clinical learning: a narrative review. Nurse Education Today. 2011 Nov 1;31(8):743-56.

36. Simelela NP, Venter WD. A brief history of South Africa's response to AIDS. SAMJ: South African Medical Journal. 2014 Mar;104(3):249-51.

\section{Tables}

Table 1: Search terms or keywords

\begin{tabular}{lc}
\hline Search keywords & Group \\
\hline NIMART or HIV training and HIV management & 1 \\
Impact of NIMART or HIV training & 2 \\
Training and HIV programme performance & 3 \\
Combination & 4 \\
\hline \hline Total & 4 \\
\hline
\end{tabular}

Source: author's own work

Table 2: databases and search results identifying the original studies 


\begin{tabular}{lc}
\hline Databases & Number of original studies \\
\hline CINAHL (EBSCO) & 320 \\
Science direct & 56 \\
Expanded Academic ASAP & 2 \\
Pro Quest & 60 \\
OAISTER & 6 \\
Business insight & 3 \\
SPORT Discuss & 6 \\
SA publications service & 37 \\
Cochrane & 1 \\
Psych Articles & 18 \\
Hein Online & 34 \\
SocINDEX & 27 \\
No data base & 10 \\
SciELO & 1 \\
\hline Total & 575 \\
\hline
\end{tabular}

Source: Author's own work

*After duplications removed

\section{Table 3: Inclusion criteria according to the PICOS review protocol}

\begin{tabular}{ll}
\hline Inclusion criteria & Description \\
\hline Participants & $\begin{array}{l}\text { Nurses, students and midwives trained on NIMART or HIV management, patients, documents, } \\
\text { literature }\end{array}$ \\
\hline $\begin{array}{l}\text { Phenomena } \\
\text { interest }\end{array}$ & $\begin{array}{l}\text { Impact of NIMART training on HIV management } \\
\text { Context }\end{array}$ \\
\hline Types of studies & The clinical environment in the PHC level initiating ART \\
\hline
\end{tabular}

Source: Author's own work

Table 4: Extracted data from original studies with quality assessments scores 


\begin{tabular}{|c|c|c|c|c|c|c|c|}
\hline $\begin{array}{l}\text { Author and } \\
\text { year }\end{array}$ & Country & Purpose & Participants & $\begin{array}{l}\text { Methodology (data } \\
\text { collection \& } \\
\text { analysis) }\end{array}$ & Key findings & QA & comments \\
\hline $\begin{array}{l}\text { Azia et al, } \\
2016\end{array}$ & $\begin{array}{l}\text { South } \\
\text { Africa }\end{array}$ & $\begin{array}{l}\text { Describe } \\
\text { challenges faced } \\
\text { by patients on } \\
\text { ART with regard } \\
\text { to adherence to } \\
\text { treatment }\end{array}$ & $\begin{array}{l}18 \text { non } \\
\text { adherence } \\
\text { patients on ART }\end{array}$ & $\begin{array}{l}\text { Descriptive } \\
\text { qualitative study, } \\
\text { purpose sampling } \\
\text {, semi structured } \\
\text { interview, manual } \\
\text { thematic analysis }\end{array}$ & $\begin{array}{l}\text { Inadequate } \\
\text { follow-ups, } \\
\text { lack of } \\
\text { confidentiality } \\
\text { Stigma, } \\
\text { unemployment, } \\
\text { lack of } \\
\text { transport, } \\
\text { insufficient } \\
\text {,disability } \\
\text { grants were } \\
\text { identified as } \\
\text { major barriers } \\
\text { to adherence }\end{array}$ & 9 & $\begin{array}{l}\text { Strong } \\
\text { Included }\end{array}$ \\
\hline $\begin{array}{l}\text { Byakika- } \\
\text { kibwika et } \\
\text { al, } 2015\end{array}$ & Uganda & $\begin{array}{l}\text { Situational } \\
\text { analysis of inter } \\
\text { professional } \\
\text { education and } \\
\text { practice for } \\
\text { ethics and } \\
\text { professionalism } \\
\text { training to } \\
\text { guide } \\
\text { development of } \\
\text { a relevant } \\
\text { training } \\
\text { curriculum of } \\
\text { ethics and } \\
\text { professionalism }\end{array}$ & $\begin{array}{l}236 \text { under } \\
\text { graduate } \\
\text { students, } 32 \\
\text { teaching health } \\
\text { professionals }\end{array}$ & $\begin{array}{l}\text { Mixed methods } \\
\text { designs, Cross } \\
\text { sectional study, } \\
\text { questionnaires } \\
\text { and FGDs and key } \\
\text { informant } \\
\text { interviews } \\
\text { Descriptive }\end{array}$ & $\begin{array}{l}\text { Inter- } \\
\text { professional } \\
\text { education } \\
\text {,practice } \\
\text {,ethics and } \\
\text { professionalism } \\
\text { are not } \\
\text { emphasize in } \\
\text { the clinical } \\
\text { years and need } \\
\text { sensitization } \\
\text { and } \\
\text { enhancement of } \\
\text { mentorship and } \\
\text { innovative } \\
\text { training } \\
\text { strategies }\end{array}$ & 8 & $\begin{array}{l}\text { Strong } \\
\text { Included }\end{array}$ \\
\hline $\begin{array}{l}\text { Bekker et } \\
\text { al, } 2016\end{array}$ & $\begin{array}{l}\text { South } \\
\text { Africa }\end{array}$ & $\begin{array}{l}\text { To provide } \\
\text { guideline on the } \\
\text { use of PrEP } \\
\text { (Tenofovir TDF/ } \\
\text { emitricitabine } \\
\text { FTC)to users } \\
\text { and health care } \\
\text { workers }\end{array}$ & $\begin{array}{l}17000 \text { people } \\
\text { from Uganda, } \\
\text { Kenya, Botswana }\end{array}$ & $\begin{array}{l}10 \text { random } \\
\text { controlled trial on } \\
\text { TDF based PrEp } \\
\text { reporting HIV } \\
\text { outcomes }\end{array}$ & $\begin{array}{l}\text { Reduction of } \\
\text { HIV requisition } \\
\text { risk by } 51 \% \text { on } \\
\text { women and } \\
\text { men } \\
\text { Development of } \\
\text { PrEp } \\
\text { guidelines for } \\
\text { southern Africa }\end{array}$ & 7 & $\begin{array}{l}\text { included } \\
\text { in } \\
\text { references }\end{array}$ \\
\hline $\begin{array}{l}\text { Bluestone } \\
\text { et al, } 2013\end{array}$ & USA & $\begin{array}{l}\text { To identify } \\
\text { effective } \\
\text { training } \\
\text { approaches for } \\
\text { health worker } \\
\text { continuing } \\
\text { professional } \\
\text { education } \\
\text { (CPE) }\end{array}$ & $\begin{array}{l}37 \text { full text } \\
\text { studies reviewed } \\
.32 \text { randomized } \\
\text { controlled trials }\end{array}$ & $\begin{array}{l}\text { Programme } \\
\text { evaluation , } \\
\text { randomized } \\
\text { control trial }\end{array}$ & $\begin{array}{l}\text { Evidence } \\
\text { suggest that } \\
\text { the use of } \\
\text { multiple } \\
\text { techniques that } \\
\text { allow } \\
\text { interaction and } \\
\text { enables } \\
\text { participants to } \\
\text { process and } \\
\text { apply } \\
\text { information and }\end{array}$ & 7 & $\begin{array}{l}\text { Strong } \\
\text { Included }\end{array}$ \\
\hline
\end{tabular}




\begin{tabular}{|c|c|c|c|c|c|c|c|}
\hline & & & & & $\begin{array}{l}\text { this includes : } \\
\text { case base } \\
\text { learning, } \\
\text { clinical } \\
\text { simulation, } \\
\text { practice and } \\
\text { feedback, } \\
\text { didactics that } \\
\text { involve passive } \\
\text { instructions } \\
\text { such as reading } \\
\text { or lecture has } \\
\text { little or no } \\
\text { impact on } \\
\text { learning } \\
\text { outcomes }\end{array}$ & & \\
\hline $\begin{array}{l}\text { Chew et al, } \\
2012\end{array}$ & USA & $\begin{array}{l}\text { Development, } \\
\text { implementation } \\
\text { and evaluation } \\
\text { of a student - } \\
\text { initiated } \\
\text { undergraduate } \\
\text { medical } \\
\text { education } \\
\text { elective in HIV } \\
\text { care to increase } \\
\text { knowledge } \\
\text { among students } \\
\text { and prepare } \\
\text { them to serve } \\
\text { the affected } \\
\text { population }\end{array}$ & $\begin{array}{l}18 \text { second year } \\
\text { students }\end{array}$ & $\begin{array}{l}\text { Programme } \\
\text { development, } \\
\text { description and } \\
\text { evaluation Self- } \\
\text { assessment of HIV } \\
\text { knowledge prior } \\
\text { and after } \\
\text { Preclerkship HIV } \\
\text { elective. Using } \\
\text { different teaching } \\
\text { strategies: } \\
\text { lecturers, small } \\
\text { group discussions, } \\
\text { clinical } \\
\text { observations, } \\
\text { community } \\
\text { placements, } \\
\text { reading } \\
\text { assignment, HIV } \\
\text { counselling and } \\
\text { testing workshop, } \\
\text { liker scale }\end{array}$ & $\begin{array}{l}\text { Increase } \\
\text { knowledge and } \\
\text { confidence in } \\
\text { serving the } \\
\text { PLWH }\end{array}$ & 8 & $\begin{array}{l}\text { Strong } \\
\text { Included }\end{array}$ \\
\hline $\begin{array}{l}\text { Colombini } \\
\text { et al } 2014\end{array}$ & USA & $\begin{array}{l}\text { Review evidence } \\
\text { on the factors } \\
\text { influencing } \\
\text { maternal and } \\
\text { infant drug } \\
\text { adherence to } \\
\text { preventing } \\
\text { MTCT drug } \\
\text { regimens at } \\
\text { delivery in Sub } \\
\text { Saharan Africa }\end{array}$ & $\begin{array}{l}14 \text { studies on } \\
\text { adherence } \\
\text { published Jan } \\
2003 \text {-september } \\
2011\end{array}$ & $\begin{array}{l}\text { Quantitative } \\
\text { research designs }\end{array}$ & $\begin{array}{l}\text { Studies reveal } \\
\text { the following as } \\
\text { factors } \\
\text { influencing } \\
\text { adherence } \\
\text { Quality and } \\
\text { timing HCT, } \\
\text { late } \\
\text { distribution of } \\
\text { NVP socio } \\
\text { demographic } \\
\text { factors }\end{array}$ & 8 & $\begin{array}{l}\text { Strong } \\
\text { Included }\end{array}$ \\
\hline $\begin{array}{l}\text { Crowley } \\
\text { and } \\
\text { Stelleberg, } \\
2015\end{array}$ & $\begin{array}{l}\text { South } \\
\text { Africa }\end{array}$ & $\begin{array}{l}\text { To evaluate the } \\
\text { adequacy of } \\
\text { pharmaceutical } \\
\text { services for the }\end{array}$ & $\begin{array}{l}20 \text { PHC } \\
\text { Facilities in } \\
\text { KZN } 12 \\
\text { provincial and } 6 \\
\text { local }\end{array}$ & $\begin{array}{l}\text { Quantitative } \\
\text { descriptive study } \\
\text { Data collection } \\
\text { instrument } \\
\text { developed in line }\end{array}$ & $\begin{array}{l}\text { Insufficient } \\
\text { storage space, } \\
\text { inadequate } \\
\text { security, poor a } \\
\text { stock outs of }\end{array}$ & 8 & $\begin{array}{l}\text { Strong } \\
\text { Included }\end{array}$ \\
\hline
\end{tabular}




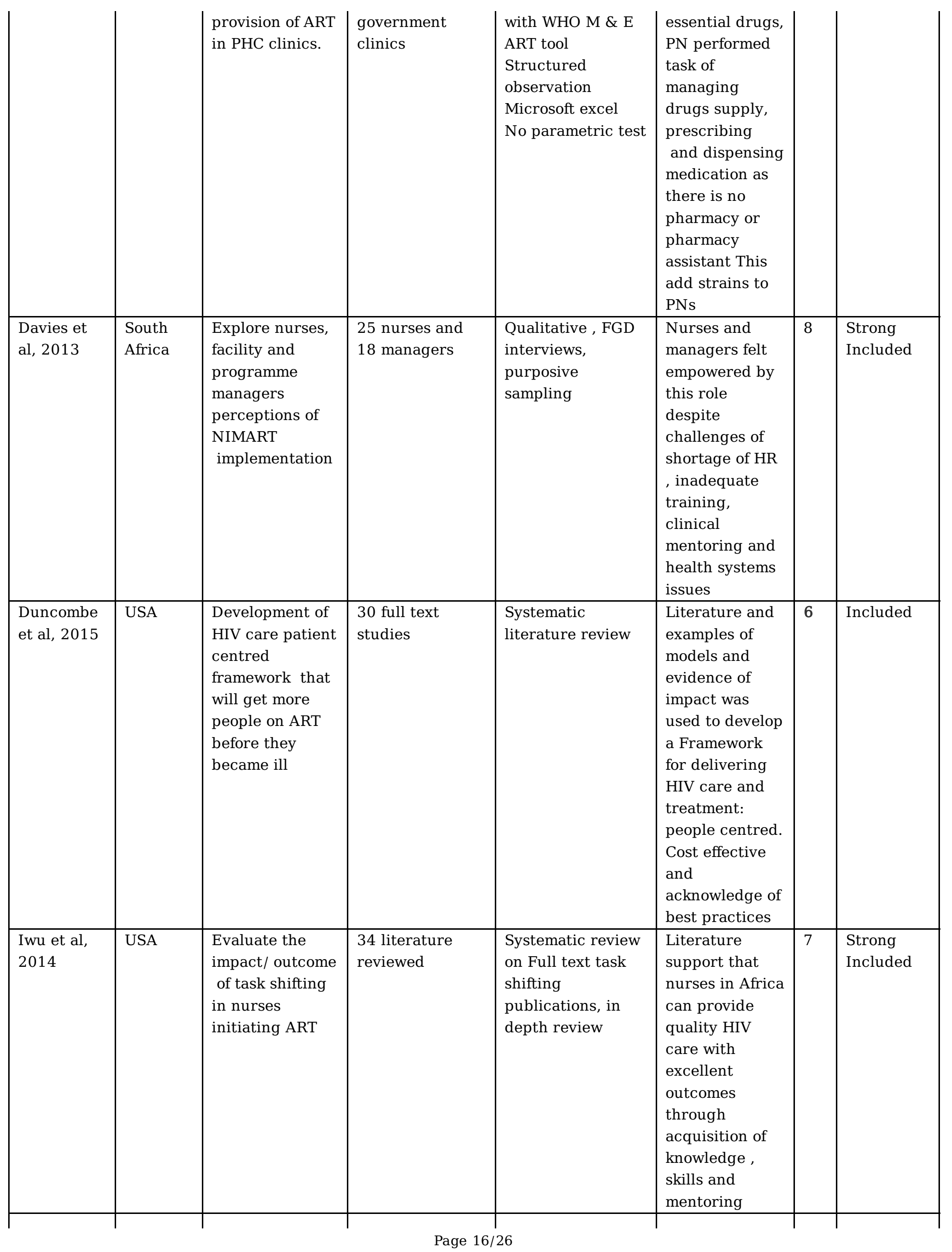




\begin{tabular}{|c|c|c|c|c|c|c|c|}
\hline $\begin{array}{l}\text { Kaposhi et } \\
\text { al, } 2014\end{array}$ & USA & $\begin{array}{l}\text { Evaluation of } \\
\text { ART programme } \\
\text { monitoring for } \\
\text { evidence based } \\
\text { decision making }\end{array}$ & $\begin{array}{l}34 \text { facilities } \\
\text { providing ART } \\
\text { by nurses in } \\
\text { rural sub } \\
\text { districts }\end{array}$ & $\begin{array}{l}\text { Qualitative study, } \\
\text { purposive } \\
\text { sampling } \\
\text { Semi structured } \\
\text { interviews, data } \\
\text { quality audits } \\
\text { SPSS version } 19 \\
\text { used to analyse } \\
\text { data }\end{array}$ & $\begin{array}{l}\text { Over reporting } \\
\text { of data due to } \\
\text { lack of training } \\
\text { on ART } \\
\text { registers, data } \\
\text { elements } \\
\text { definition } \\
\text { during } \\
\text { NIMART, Data } \\
\text { verification not } \\
\text { done by OPM, } \\
\text {,staffing levels, } \\
\text { shortage of } \\
\text { NIMART } \\
\text { trained nurses, }\end{array}$ & 6 & $\begin{array}{l}\text { Strong } \\
\text { Included }\end{array}$ \\
\hline $\begin{array}{l}\text { Knight et } \\
\text { al , } 2015\end{array}$ & SA & $\begin{array}{l}\text { Determine the } \\
\text { impact of } \\
\text { combination } \\
\text { ART initiation } \\
\text { on adherence to } \\
\text { TB Rx to reduce } \\
\text { reluctance } \\
\text { among health } \\
\text { care workers to } \\
\text { start } \\
\text { combination } \\
\text { ART in TB } \\
\text { patients }\end{array}$ & $\begin{array}{l}50 \mathrm{~TB} / \mathrm{HIV} \\
\text { patients with } \\
\mathrm{CD} 4 \text { count } 50- \\
350 \text { cells/mm. } \\
\text { Sept } 2011 \text {-Oct } \\
2012\end{array}$ & $\begin{array}{l}\text { Prospective } \\
\text { observational } \\
\text { cohort study, self- } \\
\text { report, pill count, } \\
\text { electronic } \\
\text { medication event } \\
\text { monitoring system } \\
\text { before and after } \\
\text { ART initiation } \\
\text { Questionnaire, } \\
\text { medical files } \\
\text { review analyses }\end{array}$ & $\begin{array}{l}\text { Decreased } \\
\text { adherence to } \\
\text { treatment in } \\
\text { patients with } \\
\text { TB /HIV } \\
\text { infection and } \\
\text { associated with } \\
\text { poor outcomes, } \\
\text { development of } \\
\text { resistance and } \\
\text { requires } \\
\text { adherence } \\
\text { support }\end{array}$ & 8 & $\begin{array}{l}\text { Strong } \\
\text { Included }\end{array}$ \\
\hline $\begin{array}{l}\text { Kompala et } \\
\text { al; } 2016\end{array}$ & USA & $\begin{array}{l}\text { To determine } \\
\text { impact of } \\
\text { community } \\
\text { based CD4, } \\
\text { Testing services } \\
\text { on facilitating } \\
\text { Pre art }\end{array}$ & $\begin{array}{l}160 \text { HIV positive } \\
\text { adults, } 18 \text { PHC } \\
\text { facilities }\end{array}$ & $\begin{array}{l}\text { Retrospective } \\
\text { study, comparing } \\
\text { before \& after the } \\
\text { presence of, } \\
\text { questionnaire } \\
\text { phlebotomy nurse } \\
\text { Tracing of } \\
\text { patients, referred } \\
\text { to local facility for } \\
\text { initiation based on } \\
\text { eligibility criteria, } \\
\text { Chi Square test }\end{array}$ & $\begin{array}{l}7213 \text { access } \\
\text { screening } \\
\text { services, } \\
\text { reduced loss of } \\
\text { pre ART care } \\
\text { and facilitate } \\
\text { timely access to } \\
\text { ART. } \\
\text { availability of } \\
\text { CD4 } \\
\text { phlebotomy } \\
\text { may reduce } \\
\text { loss }\end{array}$ & 8 & included \\
\hline $\begin{array}{l}\text { Kufa et al, } \\
2014\end{array}$ & USA & $\begin{array}{l}\text { To evaluate the } \\
\text { effect of an } \\
\text { intervention to } \\
\text { optimize TB/HIV } \\
\text { service } \\
\text { integration on } \\
\text { mortality, } \\
\text { morbidity and } \\
\text { retention in care } \\
\text { among newly } \\
\text { diagnosed HIV } \\
\text { and TB positive } \\
\text { patients }\end{array}$ & 18 PHC clinics & $\begin{array}{l}18 \text { Randomized } \\
\text { trial, intervention } \\
\text { and control group, } \\
\text {, ANOVA } \\
\text { statistical analyses }\end{array}$ & & 6 & $\begin{array}{l}\text { Strong } \\
\text { Included }\end{array}$ \\
\hline Mack et al, & Kenya & Identify HR & 16 public health & Qualitative study & Increased work & 8 & Strong \\
\hline
\end{tabular}




\begin{tabular}{|c|c|c|c|c|c|c|c|}
\hline 2015 & & $\begin{array}{l}\text { challenges to } \\
\text { integrating HIV } \\
\text { PrEP in to } \\
\text { public health } \\
\text { system in Kenya }\end{array}$ & stakeholders & $\begin{array}{l}\text { Semi structured } \\
\text { Interviews }\end{array}$ & $\begin{array}{l}\text { load, } \\
\text { insufficient, } \\
\text { HIV care and } \\
\text { treatment most } \\
\text { overburden } \\
\text { staff, training } \\
\text { for existing and } \\
\text { new staff, } \\
\text { create pool of } \\
\text { trainers, } \\
\text { facility based } \\
\text { trainings, } \\
\text { continuous } \\
\text { education and } \\
\text { training and } \\
\text { mentorship } \\
\text { Poor } \\
\text { infrastructure : } \\
\text { space, } \\
\text { furniture, lab } \\
\text { equipment's, } \\
\text { storage, } \\
\text { discrimination } \\
\text { and stigma }\end{array}$ & & Included \\
\hline $\begin{array}{l}\text { Mahomed } \\
\text { et al, } 2015\end{array}$ & $\begin{array}{l}\text { South } \\
\text { Africa }\end{array}$ & $\begin{array}{l}\text { Establishment of } \\
\text { structural } \\
\text { clinical record } \\
\text { as guide for } \\
\text { chronic disease } \\
\text { management to } \\
\text { improve the } \\
\text { quality of } \\
\text { clinical records } \\
\text { at PHC }\end{array}$ & $\begin{array}{l}30 \text { PHC ICDM } \\
\text { initiating clinics } \\
, 6 \text { months study } \\
20 \text { PHC clinics } \\
10 \text { intervention } \\
\text { sites and } 10 \\
\text { control sites } \\
\text { stratified } \\
\text { random } \\
\text { sampling }\end{array}$ & $\begin{array}{l}\text { Quasi comparison } \\
\text { experimental } \\
\text { study clinical } \\
\text { document review. } \\
\text { pre ( PC } 101 \text { on- } \\
\text { site training) and } \\
\text { post intervention, } \\
\text { HIV patients on } \\
\text { ART and NCDs } 19 \\
\text { records per single } \\
\text { lot structured data } \\
\text { collection tool } \\
\text { piloted }\end{array}$ & $\begin{array}{l}\text { PC } 101 \text { has the } \\
\text { potential for } \\
\text { improving the } \\
\text { quality of } \\
\text { clinical records } \\
\text { for patients } \\
\text { with chronic } \\
\text { disease in PHC } \\
\text { clinics }\end{array}$ & 9 & $\begin{array}{l}\text { Strong } \\
\text { Included }\end{array}$ \\
\hline $\begin{array}{l}\text { Makhado } \\
\text { and } \\
\text { Davhana- } \\
\text { Maselesele, } \\
2016\end{array}$ & $\begin{array}{l}\text { South } \\
\text { Africa }\end{array}$ & $\begin{array}{l}\text { To determine } \\
\text { knowledge, } \\
\text { insight and } \\
\text { uptake of } \\
\text { occupational } \\
\text { post exposure } \\
\text { prophylaxis } \\
\text { amongst nurses } \\
\text { caring for PLWH }\end{array}$ & $\begin{array}{l}233 \text { nurses } \\
\text { (ENA, EN, PN }\end{array}$ & $\begin{array}{l}\text { Quantitative Cross } \\
\text { sectional } \\
\text { descriptive } \\
\text { design, stratified } \\
\text { sampling, } \\
\text { parametric and } \\
\text { non-parametric } \\
\text { statistics, } \\
\text { Questionnaire, } \\
\text { SPSS21 }\end{array}$ & $\begin{array}{l}\text { Nurses are } \\
\text { highly exposed } \\
\text { to HIV but still } \\
\text { lack knowledge } \\
\text { on PEP, not } \\
\text { sure if the } \\
\text { service is } \\
\text { available in } \\
\text { their facilities } \\
\text { and did not } \\
\text { receive PEP } \\
\text { and to be } \\
\text { address in } \\
\text { policy, } \\
\text { guidelines and } \\
\text { programmes }\end{array}$ & 9 & $\begin{array}{l}\text { Strong } \\
\text { Included }\end{array}$ \\
\hline $\begin{array}{l}\text { Maphutego } \\
\text { et al, } 2015\end{array}$ & $\begin{array}{l}\text { South } \\
\text { Africa }\end{array}$ & & $\begin{array}{l}\mathrm{ENs}=1 / \mathrm{PNs}=33 / \\
\mathrm{Drs}=1\end{array}$ & $\begin{array}{l}\text { Exploratory } \\
\text { descriptive }\end{array}$ & $\begin{array}{l}\text { Inadequate } \\
\text { training on }\end{array}$ & 7 & $\begin{array}{l}\text { Strong } \\
\text { Included }\end{array}$ \\
\hline
\end{tabular}




\begin{tabular}{|c|c|c|c|c|c|c|c|}
\hline & & & & $\begin{array}{l}\text { qualitative Design. } \\
\text { FGDs, } \\
\text { questionnaires }\end{array}$ & $\begin{array}{l}\text { NIMART, Poor } \\
\text { integration of } \\
\text { services and } \\
\text { support, poor } \\
\text { infrastructure } \\
\text { and, long } \\
\text { waiting hours, } \\
\text { staff negative } \\
\text { attitudes, poor } \\
\text { organization of } \\
\text { work schedules } \\
\text { and processes }\end{array}$ & & \\
\hline $\begin{array}{l}\text { Mbonye eta } \\
\text { al, } 2016\end{array}$ & $\begin{array}{l}\text { South } \\
\text { Africa }\end{array}$ & $\begin{array}{l}\text { Determine } \\
\text { effectiveness of } \\
\text { educational } \\
\text { outreach in } \\
\text { infectious } \\
\text { disease } \\
\text { management }\end{array}$ & $\begin{array}{l}36 \text { health } \\
\text { facilities, mid- } \\
\text { level } \\
\text { practitioners } 9 \\
\text { clinical officers, } \\
\text { RNs or midwives } \\
\text { participated on } \\
3 \text { weeks } \\
\text { training }\end{array}$ & $\begin{array}{l}\text { Cluster } \\
\text { Randomized } \\
\text { intervention ( } \\
\text { training and } \\
\text { Onsite support, } \\
\text { CQI ) -control } \\
\text { study, pre and } \\
\text { post changes, } \\
\text { mixed design } \\
\text { medical records } \\
\text { review/ audit, } \\
\text { secondary data } \\
\text { analysis capture in } \\
\text { EPI info } \\
\text { version3.2, Ms } \\
\text { Excel frequency }\end{array}$ & $\begin{array}{l}\text { Improved } \\
\text { management of } \\
\text { cases and } \\
\text { performance of } \\
\text { indicators with } \\
\text { combination of } \\
\text { OSS and } \\
\text { training } \\
\text { however } \\
\text { workload was } \\
\text { not address }\end{array}$ & 8 & $\begin{array}{l}\text { Strong } \\
\text { Included }\end{array}$ \\
\hline $\begin{array}{l}\text { Ndubuka } \\
\text { et al, } 2016\end{array}$ & $\begin{array}{l}\text { South } \\
\text { Africa }\end{array}$ & Not indicated & $\begin{array}{l}4 \text { ART } \\
\text { clinics, } 104 \text { adult } \\
\text { ART patients for } \\
12 \text { months who } \\
\text { has stopped } \\
\text { taking ARVs for } \\
3 \text { months }\end{array}$ & $\begin{array}{l}\text { cross sectional } \\
\text { quantitative and, } \\
\text { explorative, } \\
\text { questionnaires } \\
\text { translated in local } \\
\text { language, } \\
\text { descriptive } \\
\text { statistic }\end{array}$ & $\begin{array}{l}\text { Inadequate } \\
\text { social and } \\
\text { environmental } \\
\text { support } \\
\text { structures, } \\
\text { stigma, poor } \\
\text { financial } \\
\text { resources, } \\
\text { physical living } \\
\text { conditions and } \\
\text { insecurity lead } \\
\text { to poor } \\
\text { adherence and } \\
\text { defaulting ART }\end{array}$ & 8 & $\begin{array}{l}\text { Strong } \\
\text { Included }\end{array}$ \\
\hline $\begin{array}{l}\text { Nyasulu et } \\
\text { al, } 2013\end{array}$ & $\begin{array}{l}\text { South } \\
\text { Africa }\end{array}$ & $\begin{array}{l}\text { Impact of } \\
\text { decentralization } \\
\text { of NIMART } \\
\text { rollout on the } \\
\text { referral hospital } \\
\text { by applying ten } \\
\text { steps }\end{array}$ & 17 PHC facilities & $\begin{array}{l}\text { Quasi } \\
\text { experimental } \\
\text { design, } \\
\text { interrupted time } \\
\text { series analysis, } \\
\text { Compare ART } \\
\text { before -2009 and } \\
\text { after } 2010 \text { From } \\
\text { DHIS } \\
2012 \text { Intervention: } \\
5 \text { days training, } \\
\text { pre and post-test, } \\
\text { mentoring }\end{array}$ & $\begin{array}{l}45 \text { PNs trained } \\
\& \text { mentored } \\
\text { Increased ART } \\
\text { uptake by } \\
\text { average of } 9 \\
\text { monthly in PHC } \\
\text { clinics. referral } \\
\text { facilities } \\
\text { initiations } \\
\text { decreases by } \\
\text { average of } 18 \\
\text { monthly Inc. } \\
\text { workload, }\end{array}$ & 9 & $\begin{array}{l}\text { Strong } \\
\text { Included }\end{array}$ \\
\hline
\end{tabular}




\begin{tabular}{|c|c|c|c|c|c|c|c|}
\hline & & & & $\begin{array}{l}\text { Statistical } \\
\text { analysis, auto } \\
\text { correlation ( } \\
\text { Durbin-Watson } \\
\text { statistic), excel }\end{array}$ & $\begin{array}{l}\text { however } \\
\text { capacity } \\
\text { building, } \\
\text { training, } \\
\text { mentoring and } \\
\text { integration } \\
\text { was still } \\
\text { lacking to } \\
\text { ensure quality, } \\
\text { partner driven } \\
\text {, lacks DoH buy } \\
\text { in }\end{array}$ & & \\
\hline $\begin{array}{l}\text { Nyasulu et } \\
\text { al, } 2013\end{array}$ & $\begin{array}{l}\text { South } \\
\text { Africa }\end{array}$ & $\begin{array}{l}\text { Impact of } \\
\text { decentralization } \\
\text { of NIMART } \\
\text { rollout on the } \\
\text { referral hospital } \\
\text { by applying ten } \\
\text { steps }\end{array}$ & 17 PHC facilities & $\begin{array}{l}\text { Quasi } \\
\text { experimental } \\
\text { design, } \\
\text { interrupted time } \\
\text { series analysis, } \\
\text { Compare ART } \\
\text { before -2009 and } \\
\text { after } 2010 \text { From } \\
\text { DHIS } \\
2012 \text { Intervention: } \\
5 \text { days training, } \\
\text { pre and post-test, } \\
\text { mentoring } \\
\text { Statistical } \\
\text { analysis, auto } \\
\text { correlation ( } \\
\text { Durbin-Watson } \\
\text { statistic), excel }\end{array}$ & $\begin{array}{l}45 \text { PNs trained } \\
\& \text { mentored } \\
\text { Increased ART } \\
\text { uptake by } \\
\text { average of } 9 \\
\text { monthly in PHC } \\
\text { clinics. referral } \\
\text { facilities } \\
\text { initiations } \\
\text { decreases by } \\
\text { average of } 18 \\
\text { monthly Inc. } \\
\text { workload, } \\
\text { however } \\
\text { capacity } \\
\text { building, } \\
\text { training, } \\
\text { mentoring and } \\
\text { integration } \\
\text { was still } \\
\text { lacking to } \\
\text { ensure quality, } \\
\text { partner driven } \\
\text { lacks DoH buy } \\
\text { in }\end{array}$ & 9 & $\begin{array}{l}\text { Strong } \\
\text { Included }\end{array}$ \\
\hline $\begin{array}{l}\text { Oladele et } \\
\text { al, } 2017\end{array}$ & Nigeria & $\begin{array}{l}\text { Assessment to } \\
\text { build to up } \\
\text { evidence and } \\
\text { provide baseline } \\
\text { to Accelerate } \\
\text { scaling up of } \\
\text { PMTCT services } \\
\text { in order to } \\
\text { eliminate new } \\
\text { paediatric HIV } \\
\text { infections }\end{array}$ & $\begin{array}{l}\text { Multiple } \\
\text { stakeholders: } \\
\text { health ministry, } \\
\text { DG, project } \\
\text { managers, AIDS } \\
\text { coordinators, } \\
\text { Dir. PHC, } \\
\text { regulatory } \\
\text { bodies4176 } \\
\text { facilities with } \\
\text { ANC services } \\
\text { from } 8 \\
\text { states(private } \\
\text { and public) }\end{array}$ & $\begin{array}{l}\text { Mixed methods } 10 \\
\text { months project } \\
\text { Qual-Opinions of } \\
\text { health care } \\
\text { workers, Key } \\
\text { informant } \\
\text { interviews Quant- } \\
\text { Checklist } \\
\text { /questionnaire } \\
\text {,descriptive } \\
\text { statistics }\end{array}$ & $\begin{array}{l}\text { Roll out model: } \\
\text { onsite training } \\
\text { of public, } \\
\text { NGOs, } \\
\text { traditional } \\
\text { leaders and } \\
\text { healers and } \\
\text { private health } \\
\text { care workers } \\
\text { (7224). } \\
\text { Followed by } \\
\text { post training } \\
\text { two days hands } \\
\text { on support by } \\
\text { Multi- } \\
\text { disciplinary } \\
\text { activation } \\
\text { teams, deploy }\end{array}$ & 9 & $\begin{array}{l}\text { Strong } \\
\text { Included }\end{array}$ \\
\hline
\end{tabular}




\begin{tabular}{|c|c|c|c|c|c|c|c|}
\hline & & & & & $\begin{array}{l}\text { resources. } \\
\text { Continued } \\
\text { fortnight onsite } \\
\text { mentoring } \\
\text { teams Facility } \\
\text { coverage } \uparrow 8^{-} \\
50 \% \text { Access to } \\
\text { HCT by } \\
\text { pregnant } \\
\text { woman } \\
246 \% \text { Access to } \\
\text { ART } 152 \%\end{array}$ & & \\
\hline $\begin{array}{l}\text { Omole et } \\
\text { al, } 2016\end{array}$ & $\begin{array}{l}\text { South } \\
\text { Africa }\end{array}$ & $\begin{array}{l}\text { To assess the } \\
\text { treatment } \\
\text { outcomes of an } \\
\text { HIV clinic in } \\
\text { rural areas }\end{array}$ & $\begin{array}{l}\text { 2CHC , } 18 \text { PHC } \\
\text { clinic Adult } \\
\text { patients initiated } \\
\text { on ART 2007- } \\
2008\end{array}$ & $\begin{array}{l}\text { Retrospective } \\
\text { cohort study } 124 \\
\text { Medical files } \\
\text { review } \\
\text { systematic random } \\
\text { sampling Data } \\
\text { collection tool, } \\
\text { pilot study, EPI } \\
\text { info version 6, } \\
\text { STATA version } \\
9.0 \text { descriptive } \\
\text { analysis }\end{array}$ & $\begin{array}{l}\text { Good treatment } \\
\text { outcomes is } \\
\text { achievable in } \\
\text { rural HIV clinic } \\
\text { in SA however } \\
\text { VL sand } \\
\text { adherence } \\
\text { support for } \\
\text { pregnant } \\
\text { women should } \\
\text { be enhanced to } \\
\text { reduce MTCT }\end{array}$ & 6 & $\begin{array}{l}\text { Strong } \\
\text { Included }\end{array}$ \\
\hline $\begin{array}{l}\text { Ousman et } \\
\text { al, } 2016\end{array}$ & USA & $\begin{array}{l}\text { Recruit and } \\
\text { train African } \\
\text { partnering } \\
\text { institutions to } \\
\text { provide } \\
\text { leadership } \\
\text { training on HIV } \\
\text { management, } 5 \\
\text { year programme } \\
2012-2017 \\
\text { sponsored by } \\
\text { PEPFAR, HRSA, } \\
\text { OAR from USA }\end{array}$ & $\begin{array}{l}100 \text { inter health } \\
\text { care } \\
\text { professionals } \\
\text { leaders form } \\
\text { public, private } \\
\text { and academic } \\
\text { institutions ( } \\
43 \text { nurses, } 56 \\
\text { physicians, PH } \\
\text { 2, Pharmacists, } \\
\text { 1) } 86 \text { from } \\
\text { Africa ( } \\
\text { Botswana, } \\
\text { Kenya, Uganda, } \\
\text { Tanzania, } \\
\text { Cameroon, } \\
\text { countries and } 14 \\
\text { USA }\end{array}$ & $\begin{array}{l}\text { Programme } \\
\text { development and } \\
\text { evaluation } \\
\text { Transformative } \\
\text { and innovative } \\
\text { leadership and } \\
\text { HSS training } \\
\text { conducted. } \\
\text { Participant } \\
\text { feedback and } \\
\text { direct observation, } \\
\text { journal entries, } \\
\text { skills log books } \\
\text { signed by } \\
\text { attached mentor } \\
\text { used to assess } \\
\text { trainees Biannual } \\
\text { survey of the } \\
\text { impact of the } \\
\text { programme } \\
\text { through alumni } \\
\text { Self-report, } \\
\text { competency based } \\
\text { assessment and E } \\
\text { of ,indicators } \\
\text { attach to each } \\
\text { programme }\end{array}$ & $\begin{array}{l}\text { Teaching and } \\
\text { learning } \\
\text { strategies have } \\
\text { been } \\
\text { introduced, } \\
\text { modified and } \\
\text { enhanced to } \\
\text { strengthen the } \\
\text { training } \\
\text { experience e.g. } \\
\text { more } \\
\text { interactive } \\
\text { learning, shift } \\
\text { from didactic } \\
\text { PowerPoint } \\
\text { slides } \\
\text { presentation to } \\
\text { seminar, case } \\
\text { based and } \\
\text { reflective } \\
\text { learning } \\
\text { through } \\
\text { sharing of work } \\
\text { place } \\
\text { experiences } \\
\text { work, } \\
\text { collaborative } \\
\text { learning } \\
\text { groups used to } \\
\text { dissect, and } \\
\text { analyse }\end{array}$ & 8 & $\begin{array}{l}\text { Strong } \\
\text { Included }\end{array}$ \\
\hline
\end{tabular}




\begin{tabular}{|c|c|c|c|c|c|c|c|}
\hline & & & & & $\begin{array}{l}\text { solutions to } \\
\text { complex } \\
\text { systems issues, } \\
\text { challenges and } \\
\text { barriers to } \\
\text { health care } \\
\text { Faculties } \\
\text { assign HIV } \\
\text { management } \\
\text { modules to } \\
\text { provide diverse } \\
\text { perspective on } \\
\text { the Basic and } \\
\text { advance } \\
\text { learning } \\
\text { modules } \\
\text { developed } \\
\text { Serviced based } \\
\text { learning to } \\
\text { improve health } \\
\text { care } \\
\text { professionals } \\
\text { and } \\
\text { administrative } \\
\text { personnel in } \\
\text { improving } \\
\text { healthcare } \\
\text { systems and } \\
\text { HIV care } \\
\text { delivery } \\
\text { Building } \\
\text { capacity to } \\
\text { African nursing } \\
\text { and medical } \\
\text { schools } \\
\text { including } \\
\text { international } \\
\text { council of } \\
\text { nurses }\end{array}$ & & \\
\hline $\begin{array}{l}\text { Owens and } \\
\text { Moroney, } \\
2015\end{array}$ & Australia & $\begin{array}{l}\text { To determine } \\
\text { which three } \\
\text { different } \\
\text { intervention } \\
\text { would assist } \\
\text { student } \\
\text { performance in } \\
\text { a nursing } \\
\text { bioscience }\end{array}$ & $\begin{array}{l}182 \text { high school } \\
\text { students } 44 \\
\text { underperforming } \\
\text { students }\end{array}$ & $\begin{array}{l}\text { Comparative study } \\
\text { of performance } \\
\text { and entry mark to } \\
\text { the course Prior } \\
\text { nursing bioscience } \\
\text { learning, human } \\
\text { body club and } \\
\text { online self-learn } \\
\text { smart on } \\
\text { bioscience SPSS }\end{array}$ & $\begin{array}{l}\text { Good high } \\
\text { school science } \\
\text { did improve } \\
\text { student } \\
\text { performance } \\
\text { unlike prior } \\
\text { learning } \\
\text { workshop } \\
\text { Student } \\
\text { centred } \\
\text { learning } \\
\text { improved } \\
\text { performance, } \\
\text { however human } \\
\text { body club was } \\
\text { most effective }\end{array}$ & 8 & $\begin{array}{l}\text { Strong } \\
\text { Included }\end{array}$ \\
\hline
\end{tabular}




\begin{tabular}{|c|c|c|c|c|c|c|c|}
\hline & & & & & $\begin{array}{l}\text { as it provided } \\
\text { additional } \\
\text { support }\end{array}$ & & \\
\hline $\begin{array}{l}\text { Relf et al, } \\
2011\end{array}$ & USA & $\begin{array}{l}\text { Support HIV } \\
\text { prevention, } \\
\text { care and } \\
\text { treatment } \\
\text { through training } \\
\text { and HSS in } \\
\text { response to the } \\
\text { epidemic }\end{array}$ & $\begin{array}{l}\text { Educators, } \\
\text { clinicians, policy } \\
\text { regulatory and } \\
\text { experts from sub } \\
\text { Saharan Africa }\end{array}$ & $\begin{array}{l}\text { Participatory } \\
\text { action approach }\end{array}$ & $\begin{array}{l}\text { The need for } \\
\text { competency } \\
\text { based } \\
\text { education, } \\
\text { orientation and } \\
\text { continuing } \\
\text { competency } \\
\text { validation as } \\
\text { part of license } \\
\text { renewal which } \\
\text { include } \\
\text { knowledge ( } \\
\text { mental \& } \\
\text { cognitive } \\
\text { abilities ), skills } \\
\text { ( motor } \\
\text { abilities) and } \\
\text { attitudes ( use } \\
\text { of cognitive } \\
\text { learning } \\
\text {,critical } \\
\text { thinking and } \\
\text { make } \\
\text { appropriate } \\
\text { decisions)These } \\
\text { competencies } \\
\text { should be used } \\
\text { to redesign } \\
\text { nursing and } \\
\text { midwifery } \\
\text { curriculum to } \\
\text { provide a } \\
\text { holistic } \\
\text { perspective of } \\
\text { HIV and AIDS } \\
\text { nursing } \\
\text { practice }\end{array}$ & 6 & $\begin{array}{l}\text { Excluded } \\
\text { because it } \\
\text { was } \\
\text { published } \\
\text { before } \\
2012\end{array}$ \\
\hline $\begin{array}{l}\text { Shneider,et } \\
\text { al, } 2014\end{array}$ & $\begin{array}{l}\text { South } \\
\text { Africa }\end{array}$ & $\begin{array}{l}\text { Determine the } \\
\text { impact of } \\
\text { alcohol on HIV } \\
\text { prevention and } \\
\text { treatment }\end{array}$ & $\begin{array}{l}\text { Literature with } \\
\text { alcohol risk } \\
\text { factors, }\end{array}$ & $\begin{array}{l}\text { Narrative review } \\
\text { of relevant } \\
\text { literature, AUDIT } \\
\text { tool with ten } \\
\text { questions to } \\
\text { identify severity of } \\
\text { the problem use in } \\
\text { PHC }\end{array}$ & $\begin{array}{l}\text { Heavy chronic } \\
\text { alcohol } \\
\text { consumption } \\
\text { alters } \\
\text { physiological } \\
\text { and biological } \\
\text { functioning of } \\
\text { the body cell, } \\
\text { risky sex, drug } \\
\text { interaction and } \\
\text { immune system } \\
\text { and } \\
\text { undermines } \\
\text { adherence }\end{array}$ & 6 & $\begin{array}{l}\text { Number of } \\
\text { literature, } \\
\text { sources } \\
\text { and } \\
\text { inclusion } \\
\text { criteria } \\
\text { was not } \\
\text { indicated }\end{array}$ \\
\hline
\end{tabular}




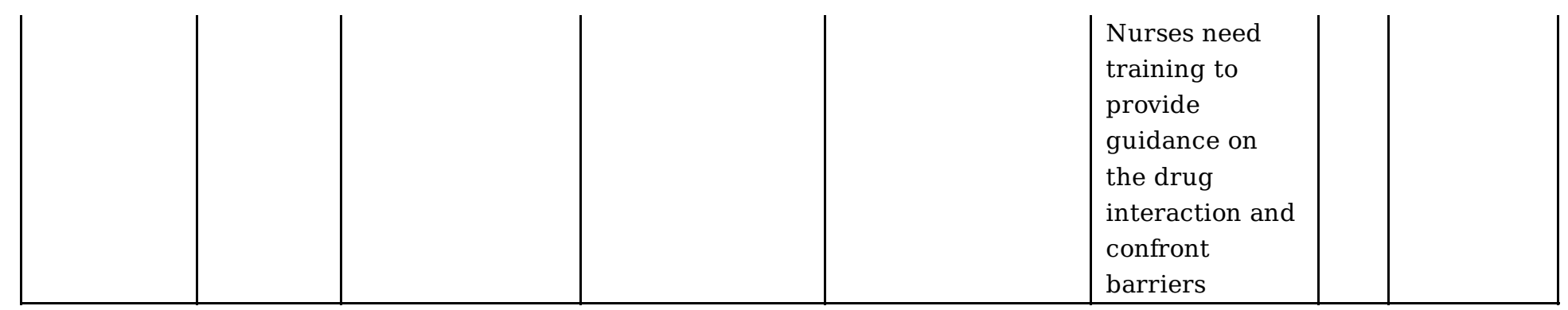

\section{Table 5: Thematic analysis of the NIMART/HIV training strategies}

\begin{tabular}{|c|c|}
\hline \multirow{6}{*}{$\begin{array}{l}\text { Theme1: Positive strategies } \\
\text { impacting on NIMART/HIV } \\
\text { training }\end{array}$} & $\begin{array}{l}\text { Use of Interactive teaching strategies to stimulate critical thinking which } \\
\text { includes problem-based, reflective, case studies and seminars. }\end{array}$ \\
\hline & Use of competency-based education and training \\
\hline & capacity building and training through pre-service \\
\hline & $\begin{array}{l}\text { Onsite training on PC } 101 \text { training improves recording and integration of non- } \\
\text { communicable diseases (NCDs) with HIV }\end{array}$ \\
\hline & Onsite continuous facility training on current development and gaps. \\
\hline & Continuous professional development and onsite facility mentoring \\
\hline \multirow[t]{10}{*}{$\begin{array}{l}\text { Theme 2: Negative strategies } \\
\text { impacting on NIMART/HIV } \\
\text { training }\end{array}$} & $\begin{array}{l}\text { Ineffective training methods which include the use of traditional didactics like } \\
\text { lecture methods and slides presentation have no impact on learning and } \\
\text { implementation. }\end{array}$ \\
\hline & $\begin{array}{l}\text { A lack of pre-service NIMART training in institutions of higher learning makes } \\
\text { students lack skills to manage HIV. }\end{array}$ \\
\hline & Inadequate clinical onsite mentoring, partner-driven only. \\
\hline & Inadequate in-service training on current developments \\
\hline & $\begin{array}{l}\text { A lack of continuous professional development (CPD) to improve knowledge and } \\
\text { skills. }\end{array}$ \\
\hline & Inadequate and unskilled trainers \\
\hline & Inadequate training period (5 days). \\
\hline & Unintegrated training curriculum in pre- or service training and education \\
\hline & $\begin{array}{l}\text { Inadequate training on data management, elements definition, clinical registers } \\
\text { or stationery. }\end{array}$ \\
\hline & Inadequate training \& implementation of PC 101. \\
\hline
\end{tabular}

Source: Author's own work

Table 6: Thematic analysis of factors influencing the implementation of NIMART/HIV training 


\begin{tabular}{|c|c|}
\hline \multirow[t]{11}{*}{ Theme 3: Structural or healthcare System factors } & Lack of regulation on NIMART \\
\hline & Inadequate follow-ups and tracing \\
\hline & Drugs stock-outs \\
\hline & Long working hours \\
\hline & Poor work schedules and processes \\
\hline & Poor integration of services \\
\hline & Stigma and discrimination \\
\hline & Inadequate leadership role model \\
\hline & Poor management support \\
\hline & Poor clinical supervision \\
\hline & Poor data management \\
\hline \multirow[t]{4}{*}{ Theme 4: Environmental factors } & Poor infrastructure Not enough space for clients \\
\hline & Overcrowding \\
\hline & Not enough space for storing drugs \\
\hline & Inadequate security Exposure to infection \\
\hline \multirow[t]{10}{*}{ Theme 5: Health care provider factors } & Negative staff attitudes \\
\hline & Staff overworked/ overburden \\
\hline & Dissatisfaction \\
\hline & Lack of confidence \\
\hline & Shortage of skilled healthcare workers \\
\hline & Nurses still performing work of pharmacists \\
\hline & Poor data verification \\
\hline & Inability to interpret lab results \\
\hline & Poor competence \\
\hline & High staff turnover \\
\hline \multirow[t]{4}{*}{ Theme 6: Patient factors } & Poor lifestyle \\
\hline & Poor Adherence \\
\hline & Stigma and discrimination, lost to follow up (LTFU) \\
\hline & Social, Psychological \& physical factors \\
\hline
\end{tabular}

\section{Source: author's own work}

\section{Figures}




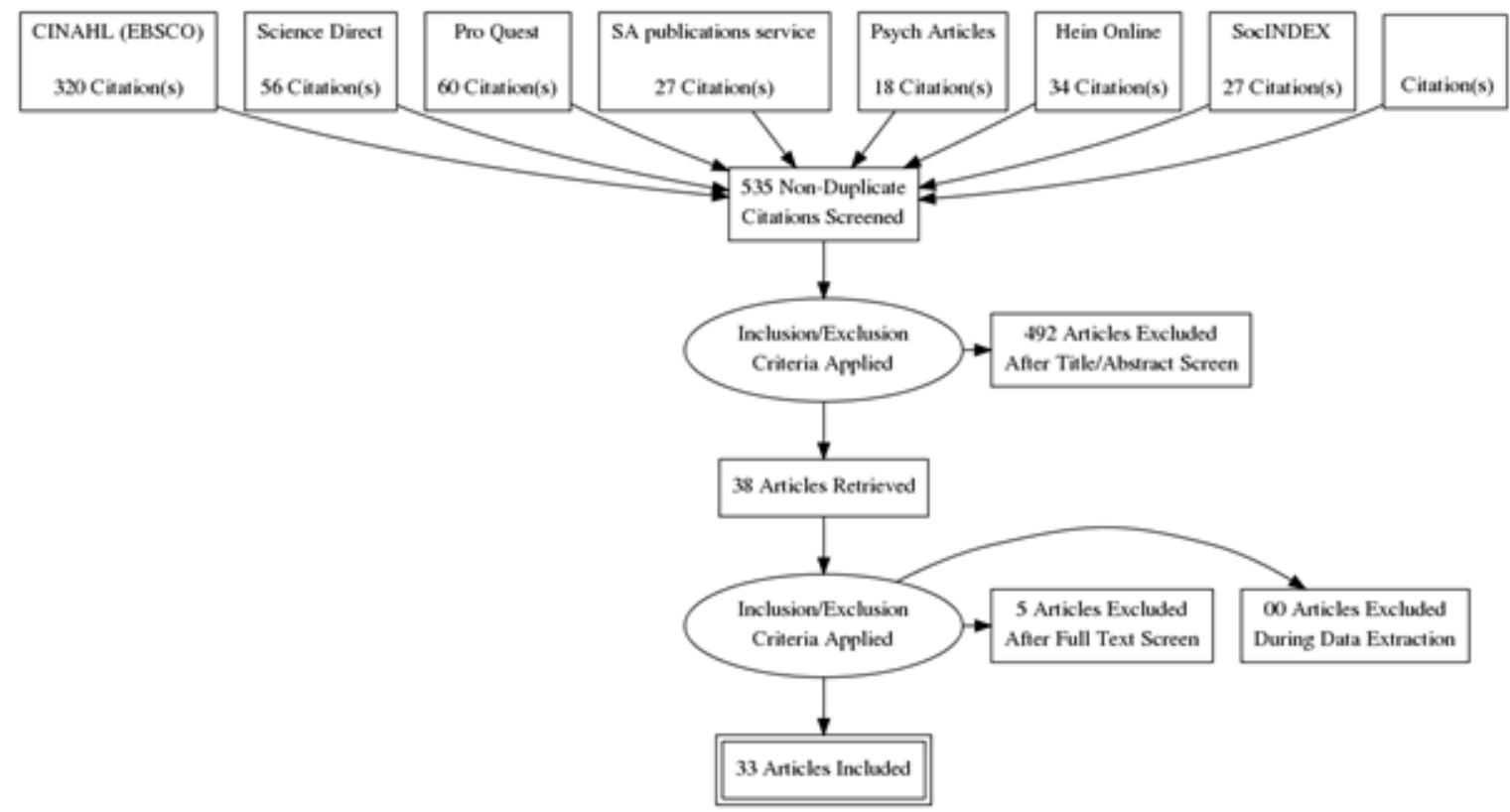

Figure 1

PRISMA flow diagram 